\title{
ASSESSING CARBON SEQUESTRATION CAPACITY OF FOREST AND PROPOSING SOLUTIONS TO GREENING INDUSTRIES IN VIETNAM
}

\author{
Nguyen Thi Anh Tuyet ${ }^{* 1}$, Nguyen Thuy Chung ${ }^{1}$, and Trieu Hung ${ }^{2}$ \\ ${ }^{1}$ School of Environmental Science and Technology, Hanoi University of Science and Technology, Hanoi, \\ Vietnam, Tel: +84904861412, e-mail: tuyet.nguyenthianh@hust.edu.vn \\ ${ }^{2}$ Vietnam Industrial Forestry Association, Hanoi, Vietnam
}

Received Date: February 13, 2020; Revised Date: December 19, 2020; Acceptance Date: February 17, 2021

\begin{abstract}
Aiming to reduce GHG emissions in order to limit and prevent climate change response in Vietnam, decree 99/2010/ND-CP about payment for forest environmental services (PFES) went into effect since Jan 2011. After years of implementation, the policy has brought positive impacts and mobilized remarkable financial resources for forest management, protection and development and also improve living standard of people whose lives depend on the forest. However, until now PFES has focused on target sectors of clean water and tourism; other potential sectors such as industrial companies, have not been applied. This research aims to identify opportunities and challenges of Carbon PFES from industrial companies that have been causing large GHGs emission. Quang Ninh and Thanh Hoa - the two largest provinces in Vietnam are selected to collect data and estimate GHG emissions from coal-fired thermal power plants and cement plants; and also to identify sequestration capacity of forest-based $\mathrm{C}$ services that are providing boundary in the two provinces. As the result, average emission factors for pulverized coal, circulating fluidized bed and rotary kiln technology were $1.05 \mathrm{tCO}_{2} / \mathrm{MWh}, 1.11 \mathrm{tCO} / \mathrm{MWh}$ and $0.85 \mathrm{tCO}_{2} /$ ton of clinker, respectively. In 2018, total $\mathrm{CO}_{2}$ emissions from thermal power and cement industry in Thanh Hoa and Quang Ninh were 11,395,545 tCO 2 , and 31,938,232 $\mathrm{tCO}_{2}$, respectively. Meanwhile, $\mathrm{CO}_{2}$ absorption capacity of all forest types in these two provinces were 4,302,474 $\mathrm{tCO}_{2}$ and $3,191,060 \mathrm{tCO}_{2}$, respectively. It means about $38 \%$ of $\mathrm{CO}_{2}$ emitted in the year from these industries can be absorbed by the forests in Thanh Hoa and about only $10 \%$ of that can be absorbed by the forests in Quang Ninh. It is also found that more than $17 \%$ of $\mathrm{CO}_{2}$ yearly emitted from both industries can be absorbed by the forests in both provinces. This research proposes scope of Carbon-PFES for the industrial sectors in Vietnam that meet GHG emission reduction targets.
\end{abstract}

Keywords: Carbon sequestration capacity, Carbon payment for forest environmental services (CPFES), Cement industry, GHG emission, Thermal power plant

\section{Introduction}

Under the 2014 Paris Agreement, the parties joined the United Nations Framework Convention on Climate Change (UNFCCC) and agreed to cut greenhouse gas (GHG) emissions to ensure global temperatures do not exceed $1.5^{\circ} \mathrm{C}$ above the levels when not yet industrialized and avoiding the devastating effects of climate change on ecosystems, economies, and social systems worldly. To achieve this goal requires great efforts from countries all over the world, because most of countries often turn to market mechanisms when they want to make a realistic 
assessment of economic restructuring, they still must balance social and environmental needs. In 2015, the Vietnamese government submitted an Intended Nationally Determined Contribution Report to the UNFCCC, which Vietnam, by 2030, pledged to reduce its domestic sources of the GHG emissions compared to the normal development scenario by $8 \%$; to reduce $20 \%$ of emission intensity per unit of GDP and to increase forest cover to $45 \%$. This means that reducing emissions and protecting and developing forests will be carried out simultaneously. Protecting and developing forests to achieve forest cover of $45 \%$ is also an important measurement to reduce GHG emissions.

Payment for forest carbon sequestration and storage (C-PFES) is an economic tool to adjust the behaviour of organizations and individuals towards reducing GHG emissions into the environment, bringing the cost of reducing GHG emissions in the production-sale process into the cost according to the Beneficiary Pays Principle [1-4]. This study focuses on: (i) investigating the $\mathrm{CO}_{2}$ (the mostly GHG) emissions from industrial plants, forest carbon sequestration and storage capacity in provinces; and (ii) contributing to the implementation of green growth strategy and responding to climate change, implementing the Government's commitment to reduce GHG emissions and increase forest cover.

Globally, emissions from the energy sector, including electricity production, accounting for $45 \%$ of global emissions are the largest source of global GHG emissions. The cement manufacturing industry is responsible for $5 \%$ of global emissions. This is also the area often targeted for emission reduction [5]. In Vietnam, each thermal power plant or cement plant emits millions of tons of $\mathrm{CO}_{2}$ per year. The results of national $\mathrm{GHG}$ inventories published in the two most recent national reports $[6,7]$ also indicate that the thermal power sector and cement industry are always the largest GHG emission sources (except for irrigation sector). Thanh Hoa and Quang Ninh are the two largest provinces in Vietnam, respectively represent the North Central and Northeast regions. Our preliminary survey results show that there are 19 facilities that are major GHG emitters in these provinces, including 7 coal-fired thermal power plants and 12 cement plants. $\mathrm{CO}_{2}$ emission from coal-fired thermal power plants in Quang Ninh account for more than $26 \%$ of total $\mathrm{CO}_{2}$ emitted from all thermal power plants in the country. For cement production, $\mathrm{CO}_{2}$ emission from cement plants in Thanh Hoa is largest among other provinces. Both provinces have relatively large forest areas, and they are the operating sites of "Support for REDD+ Readiness in Vietnam - Phase 2 (2015-2018)" project.

The concept of C-PFES is relatively new in Vietnam. Firstly, this study obtains specific data from targeted production establishments currently operating in Thanh Hoa and Quang Ninh and provides calculation methods to determine large $\mathrm{CO}_{2}$ emission quotas. Then, to have a basis for calculating the amount of $\mathrm{CO}_{2}$ absorbed and creating a favourable first step for the process of trading $\mathrm{CO}_{2}$ emissions, the $\mathrm{CO}_{2}$ absorption capacity of some major plantations in the provinces has been researched.

\section{Methodology}

This part presents methods to determine: (i) $\mathrm{CO}_{2}$ emissions in coal-fired thermal power plants and cement production plants; and (ii) $\mathrm{CO}_{2}$ absorption and storage capacities of the forests in Thanh Hoa and Quang Ninh. All formulas are followed the updated IPCC guidance [8]. The 
values of emission factors of coal types of Vietnam are corrected using correction coefficients. Correction coefficient for each coal type is the ratio of net calorific value of that coal type to the standard anthracite coal. To get full correction data, a survey has been carried out on all the coalfired thermal power plants and cement plants in Thanh Hoa and Quang Ninh.

\section{Method to Determine $\mathrm{CO}_{2}$ Emissions in Coal-fired Thermal Power and Cement Industry}

Coal-fired thermal power industry in Vietnam is using two types of boiler technology: pulverized coal (PC) and circulating fluidized bed (CFB). The amount of $\mathrm{CO}_{2}$ emitted at the thermal power plant mainly comes from the use of fuel for steam production. Besides, there is also $\mathrm{CO}_{2}$ emission due to the thermal reaction of limestone for circulating boiling coal layer technology. This CFB technology uses low-quality coal with high sulfur content, which requires spraying of limestone to absorb $\mathrm{SO}_{2}$ components generated during combustion process.

Cement production stages include clinker producing (burning) and clinker grinding. The amount of $\mathrm{CO}_{2}$ emitted at the cement plant is mainly from the use of fuel and limestone for the clinker burning process. Clinker grinding stage to create cement products only consumes electricity, so it does not directly emit $\mathrm{CO}_{2}$.

Total amount of $\mathrm{CO}_{2}$ emitted in coal-fired thermal power plants as well as in cement production plants is formulated as follows:

$$
E_{\text {total }}=E_{\text {fuel }}+E_{\text {lime }}
$$

Where:

- Etotal: Total $\mathrm{CO}_{2}$ emissions in each thermal power unit or cement line (ton)

- Efuel: $\mathrm{CO}_{2}$ emissions due to the use of fuel (firing coal) (ton)

- Elime: $\mathrm{CO}_{2}$ emissions due to the use of limestone (ton)

\section{Determination of $\mathrm{CO}_{2}$ Emissions due to Fuel Use}

The formula for calculating the annual $\mathrm{CO}_{2}$ emissions by using coal in each thermal power unit or cement line is as follows [8]:

$$
E_{\text {fuel }}=\sum_{i} F C_{i} \times N C V_{i} \times E F_{C O 2, i} \times C F_{i} \times C F_{\text {combus }}
$$

Where:

- Efuel: $\mathrm{CO}_{2}$ emissions due to fuel use in the thermal power unit or cement line (ton)

- $\mathrm{FC}_{\mathrm{i}}$ : Consumption of type-i coal in the thermal power unit or cement line in the year (ton) - This data was surveyed on-site

- $\mathrm{NCV}_{\mathrm{i}}$ : Net calorific value of standard anthracite coal $(=37.3 \mathrm{GJ} / \mathrm{t})$ - This data is referred from IPCC [8]

- $\mathrm{EFCO}_{\mathrm{C}, \mathrm{i}} \mathrm{CO}_{2}$ emission factor of standard anthracite coal $\left(=0.0983 \mathrm{tCO}_{2} / \mathrm{GJ}\right)-$ This data is referred from IPCC [8] 
- $\mathrm{CF}_{\mathrm{i}}$ : Correction coefficient of calorific value of type-i coal compared with standard anthracite coal. Net calorific value of type-i coal is specified in TCVN 8910:2015 Commercial coal standard: Technical requirements

- $\mathrm{CF}_{\text {combus: }}$ Fire efficiency in practice (\% $\mathrm{C}$ burns in practice compared to theory) This data was surveyed on-site

\section{Determination of $\mathrm{CO}_{2}$ Emissions due to the Use of Limestone}

The formula for calculating annual $\mathrm{CO}_{2}$ emissions due to the use of limestone for $\mathrm{CFB}$ technology is shown as follows [9]:

$$
E_{\text {lime }}=L \times E F_{\text {CO2,lime }} \times C F_{\text {lime }}
$$

Where:

- Elime: $\mathrm{CO}_{2}$ emissions due to the use of limestone to absorb $\mathrm{SO}_{2}$ components (ton)

- L: Consumption of limestone in the year (ton) - This data was surveyed on-site

- EFCO2,lime: $\mathrm{CO}_{2}$ emission factor of limestone calcination $\left(=0.44 \mathrm{kgCO}_{2} / \mathrm{kgCaCO}_{3}\right)-$ This data is calculated from a calcination reaction of limestone with the assumption that a reaction efficiency of $100 \%$

- $\mathrm{CF}_{\text {lime: }}$ Calcined limestone efficiency in practice $(\% \mathrm{CaO}$ obtained in practice compared to theory) - This data was surveyed on-site

The formula for calculating annual $\mathrm{CO}_{2}$ emissions due to the use of limestone in each cement line is as follows [9]:

$$
E_{\text {lime }}=L \times E F_{\text {CO2,clinker }} \times C F_{\text {ckd }}
$$

Where:

- Elime: $\mathrm{CO}_{2}$ emissions due to the use of limestone input (ton)

- L: Consumption of limestone in the year (ton) - This data was surveyed on-site

- EFCO2,clinker: $\mathrm{CO}_{2}$ emission factor of clinker (=0.51 $\mathrm{tCO}_{2} /$ ton of clinker) - This emission factor is calculated according to the formula (5) below

- $\mathrm{CF}_{\mathrm{ckd}}$ : Compensation coefficient of CKD for dust emissions from clinker kilns (1.02)

The formula for calculating an emission factor of the clinker is as follows:

$$
E F_{C O 2, \text { clinker }}=\text { Scale factor } \times \text { CaO content in clinker }
$$

Scaling factor is $0.786 \mathrm{tCO}_{2} /$ ton $\mathrm{CaO}$, which is the ratio of molecular weight between $\mathrm{CO}_{2}$ and $\mathrm{CaO}$. The value of 0.65 is used for the $\mathrm{CaO}$ content in clinker according to Vietnam

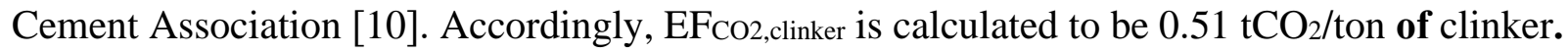




\section{Method to Determine Carbon Absorption and Storage Capacity of the Forests}

Methods of calculating reserves, increasing reserves, biomass and determining forest carbon absorption and storage capacity of the forests are carried out according to:

(i) Guidelines of the IPCC in $2006[11,15]$

(ii) Research results on monitoring changes in forest resources; including the application of some default coefficients and specific lookup data

(iii) Results of the forest inventory in Quang Ninh province in 2015 [12]

(iv) Results of the forest inventory in Thanh Hoa province in 2015 [13]

(v) Regulations on benefit sharing from Reducing Emissions from Deforestation and Forest Degradation within the framework of implementing the UN-REDD Vietnam Program - Phase II [14]

Reference level of each forest type is determined by the average timber volume $\left(\mathrm{m}^{3} / \mathrm{ha}\right)$ of that forest type, usually calculated for each region or country, in the two pilot provinces, Quang Ninh belongs to the Northeast Region while Thanh Hoa belongs to the North Central region. Forest carbon stock, in other words is the forest's carbon storage capacity, is determined by the following steps: from the forest reserve $\left(\mathrm{m}^{3} / \mathrm{ha}\right)$, the amount of biomass (ton/ha) is determined; from the amount of biomass, the carbon source (ton/ha) is determined; and from the carbon source, the amount of $\mathbf{C O}_{2}$ (ton/ha) is calculated. Similarrly, carbon absorption capacity of each forest type is determined based on the basic of the average annual volume growth of that forest type: forest reserve growth $\left(\mathrm{m}^{3} / \mathrm{ha} /\right.$ year $) \rightarrow$ biomass growth (ton/ha/year) $\rightarrow$ carbon source growth $\rightarrow$ (ton/ha/year) $\rightarrow \mathbf{C O}_{2}$ growth (ton/ha/year)

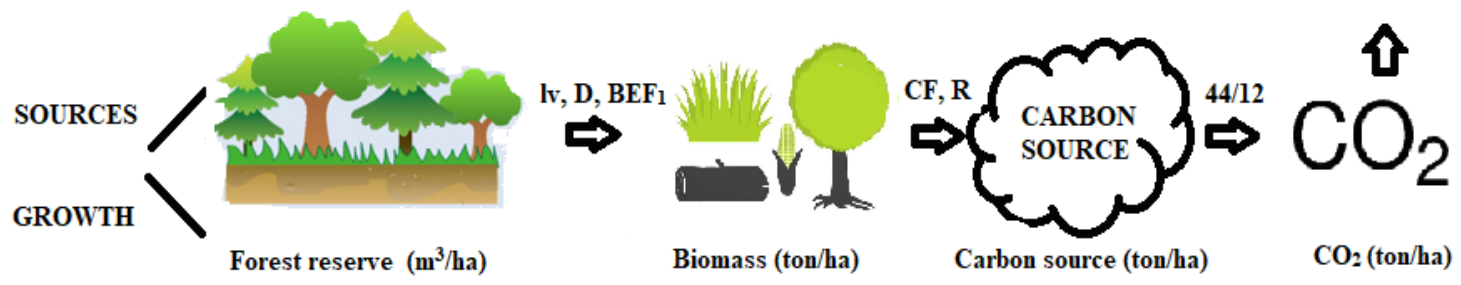

Amount of $\mathrm{tCO}_{2}$ is calculated as follows [11]:

$$
m=\left(l v \times D \times B E F_{1}\right) \times(1+R) \times C F \times 44 / 12
$$

Where:

- m: Annual $\mathrm{CO}_{2}$ absorption capacity $\left(t \mathrm{CO}_{2}\right)$

- lv: Annual growth rate of the forest $\left(\mathrm{m}^{3}\right)$ - This data is the 2015 forest inventory data in Quang Ninh and Thanh Hoa, within the framework of WB-ERPD Program [12, 13]

- D: Density of wood: natural forest $=0.55$, planted forest $=0.5$ - This data is referred from from the pilot REDD++ project, within the framework of implementing the UN-REDD Vietnam Program [14] 
- BEF1: Biomass conversion factor: natural forest $=1.3$; plantation forest $=1.2-$ This data is referred from IGES [14]

- R: Root biomass to stem biomass $=0,2-$ This data is referred from IPCC [15]

- CF: Carbon coefficient $=0.47$ - This data is referred from IPCC [15]

\section{Results and Discussion}

\section{Data Sources in Thanh Hoa and Quang Ninh}

\section{Data Sources to Determine $\mathrm{CO}_{2}$ Emissions from Industrial Facilities}

Thanh Hoa currently has 4 cement plants (with 7 rotary kiln lines as shown in Table 1) and 1 thermal power plant operating. These are large $\mathrm{CO}_{2}$ emission facilities due to their large capacity and intensive energy (especially coal) usage for combustion. In 2017, the total design capacity reached 40,000 tons of clinker/day, equivalent to 14.9 million tons of cement/year, accounting for more than $15 \%$ of the total design capacity of whole industry (nationwide).

Table 1. List of Rotary Kiln Lines in Thanh Hoa in 2017

\begin{tabular}{llcr}
\hline & & \multicolumn{2}{c}{ Production Capacity } \\
\cline { 3 - 4 } No. & Cement Plants & \multicolumn{1}{c}{$\begin{array}{r}\text { Ton of } \\
\text { Cement/year }\end{array}$} \\
\hline $\mathbf{1}$ & Bim Son 2 & 4,000 & $1,400,000$ \\
$\mathbf{2}$ & Bim Son 3 & 5,500 & $2,000,000$ \\
$\mathbf{3}$ & Long Son & 6,000 & $2,200,000$ \\
$\mathbf{4}$ & Cong Thanh 1 & 2,500 & 910,000 \\
$\mathbf{5}$ & Cong Thanh 2 & 10,000 & $4,000,000$ \\
$\mathbf{6}$ & Nghi Son & 6,000 & $2,200,000$ \\
$\mathbf{7}$ & Nghi Son 2 & 6,000 & $2,200,000$ \\
\hline
\end{tabular}

Quang Ninh currently has 4 cement plants (with 5 rotary kiln lines including 3 large capacity lines and 2 small capacity lines as shown in Table 2) and 7 thermal power plants operating (Table 3). Those are large $\mathrm{CO}_{2}$ emission sources due to the use of energy (especially coal) for combustion. Among the plants, Thang Long thermal power started operation in 2017. 
Table 2. List of Rotary Kiln Lines in Quang Ninh in 2017

\begin{tabular}{|c|c|c|c|}
\hline \multirow[b]{2}{*}{ No. } & \multirow[b]{2}{*}{ Cement Plants } & \multicolumn{2}{|c|}{ Production Capacity } \\
\hline & & Ton of Clinker/day & $\begin{array}{r}\text { Ton of } \\
\text { Cement/year } \\
\end{array}$ \\
\hline 1 & Cam Pha & 6,000 & $2,200,000$ \\
\hline 2 & Ha Long & 5,500 & $2,000,000$ \\
\hline 3 & Lam Trach 1 & 1,200 & 450,000 \\
\hline 4 & Lam Trach 2 & 1,200 & 450,000 \\
\hline 5 & Thang Long & 6,000 & $2,200,000$ \\
\hline
\end{tabular}

Regarding thermal power industry, among the 30 coal-fired thermal power units nationwide, the largest units are concentrated in Quang Ninh. Among 11 PC power plants participating in the national competitive generation market, there are 4 plants in Quang Ninh, contributing more than $53 \%$ of the total capacity.

Table 3. List of Coal-Fired Thermal Power Units in Quang Ninh in 2017

\begin{tabular}{llcrr}
\hline No. & Thermal Power Plants & Technology & Capacity, MW & $\begin{array}{r}\text { Output/year, } \\
\text { MWh }\end{array}$ \\
\hline $\mathbf{1}$ & Mong Duong 2 & PC & 1,200 & $7,600,000$ \\
$\mathbf{2}$ & Quang Ninh & PC & 1,200 & $7,600,000$ \\
$\mathbf{3}$ & Mong Duong 1 & CFB & 1,080 & $6,500,000$ \\
$\mathbf{4}$ & Cam Pha & CFB & 670 & $3,680,000$ \\
$\mathbf{5}$ & Uong Bi 2 & PC & 630 & $3,000,000$ \\
$\mathbf{6}$ & Mao Khe & CFB & 440 & $2,600,000$ \\
$\mathbf{7}$ & Thang Long & CFB & 620 & $1,283,000$ \\
\hline
\end{tabular}

Data Sources to Determine Carbon Absorption and Storage Capacity of the Forests

The following list is data sources used to determine carbon absorption and storage capacity of Thanh Hoa and Quang Ninh: 
- Forest inventory results of both provinces in 2015 [12, 13]

- Piloting benefit sharing from REDD+ [14]

- Decision on alternative afforestation of Thanh Hoa and Quang Ninh

- Monitoring data of national forest resources in cycles I, II, III and IV of FIPI.

The classification system of forest and land use types under the National Forest Inventory and Monitoring Program are relatively detailed and rather complex. In this study, the WB-ERPD Program of GHG emissions reduction in six central provinces was referenced. The Vietnamese forests are classified into 4 groups as follows:

- Natural wood forest, including 3 types: rich, medium and poor forests, regardless of whether they are primary or secondary, coniferous or broadleaf

- Other natural forests, including natural forests of bamboo forest, mixed woodbamboo forests, mixed forests of bamboo-timber, palm-trees, etc.

- Planting forests, including: Short-term fast-growing tree planting forests ( $\leq 6$ years), Large-sized fast-growing planted forests with long-term trees ( $\geq 12$ years), Largesized indigenous planted forests (cycles $\geq 20$ years), Mangrove plantation forests ( $\geq$ 20 years), Rubber plantations, specialty trees and agroforestry combined with $\geq 15 \%$ of canopy cover and perennial timber trees ( $\geq 20$ years cycle)

- Non-forest land: including vegetation statuses of Ia, Ib, Ic and bare land planned for forestry. These vegetation types are not participating in the pilot of C-PFES service.

\section{$\mathrm{CO}_{2}$ Emissions in Thanh Hoa and Quang Ninh}

\section{$\mathrm{CO}_{2}$ Emissions from Coal-fired Thermal Power Sector and Cement Industry}

Applying the calculation formulas presented above, total $\mathrm{CO}_{2}$ emission at 8 thermal power plants in Quang Ninh and Thanh Hoa are presented in Figure 1.

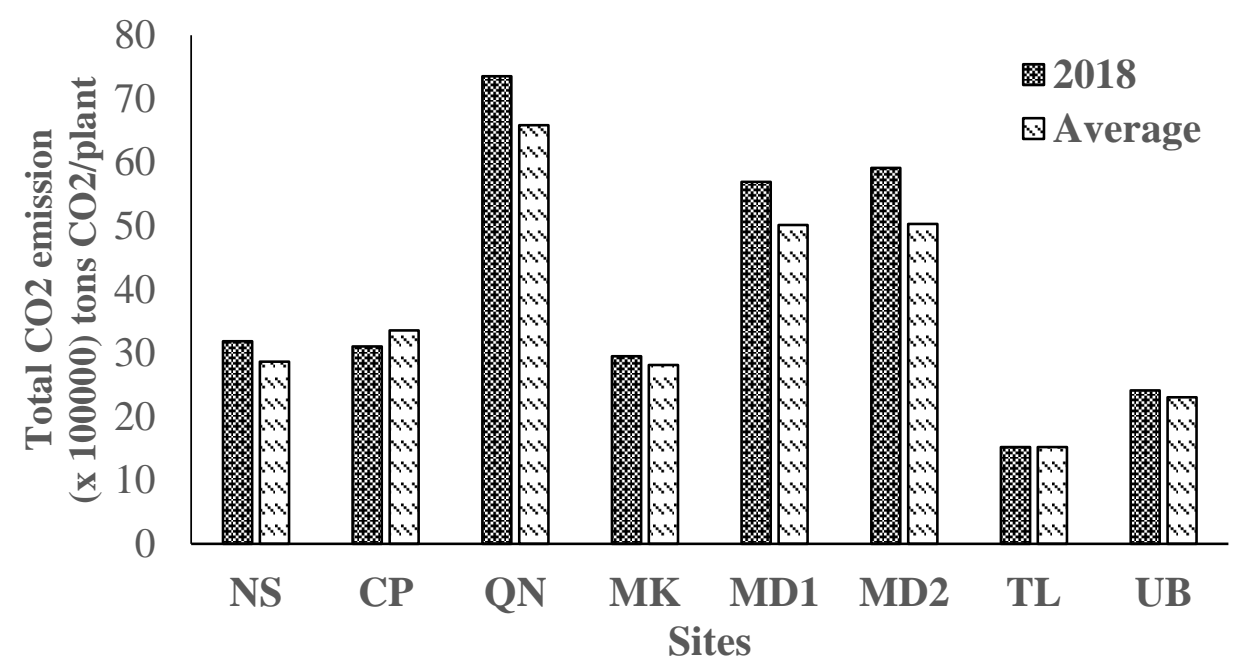

Figure 1. $\mathrm{CO}_{2}$ emission from the thermal power plants in 2018 and average 5 years (2013-2018) (Notes : NS: Nga Son, CP: Cam Pha, QN: Quang Ninh, MK: Mao Khe, MD1: Mong Duong 1, $M D$ 2: Mong Duong 2, TL: Thang Long, UB: Uong Bi) 
In total, all thermal power plants have large emission bases, emitting from $1.5-7.3$ million tons of $\mathrm{CO}_{2} /$ year.

The average annual emission is about 3.7 million tons of $\mathrm{CO}_{2} /$ facility/year. The average emission factor of plant over the years is 1.08 tons of $\mathrm{CO}_{2} / \mathrm{MWh}$.

Where:

- Average emission factor for PC technology is 1.05 tons of $\mathrm{CO}_{2} / \mathrm{MWh}$

- Average emission factor for CFB technology is 1.11 tons $\mathrm{CO}_{2} / \mathrm{MWh}$

Applying the calculation formulas presented above to cement industry, total $\mathrm{CO}_{2}$ emissions at 8 cement plants in Thanh Hoa and Quang Ninh are determined and showed in Figure 2.

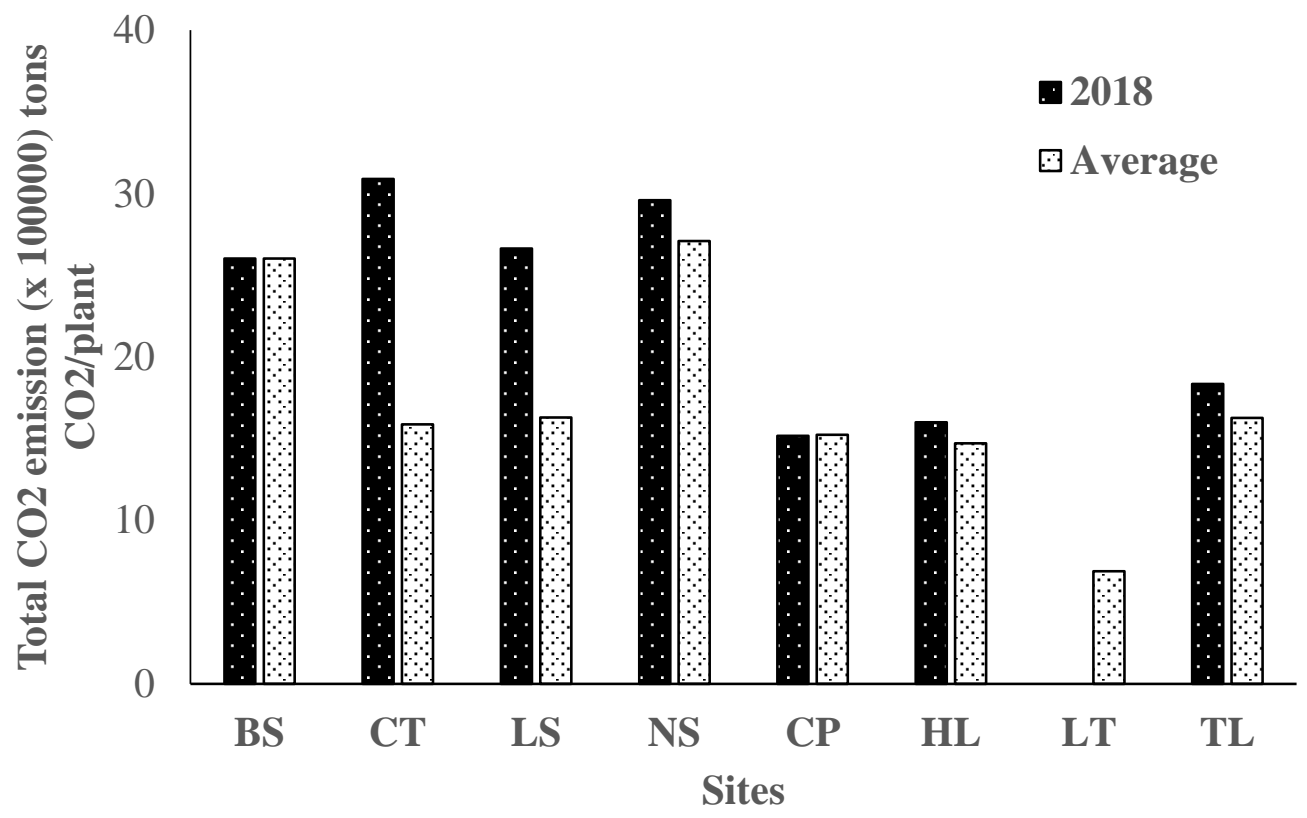

Figure 2. $\mathrm{CO}_{2}$ emission from the cement plants in 2018 and average 5 years (2013-2018) (Notes : BS: Bim Son, CT: Cong Thanh, LS: Long Son, NS: Nghi Son, CP: Cam Pha, HL: Ha Long, LT: Lam Thach, TL: Thang Long)

In total, all cement plants are large emission bases, emitting from $\sim 0.7-3.1$ million $\mathrm{tCO}_{2} /$ year. The average annual emission is 1.73 million $\mathrm{tCO}_{2} /$ facility/year. The average emission factor of factories over the years is: $0.85 \mathrm{tCO}_{2} /$ ton of clinker.

\section{$\mathrm{CO}_{2}$ Emissions from Thanh Hoa and Quang Ninh}

As resulted, $\mathrm{CO}_{2}$ emissions from thermal power industry in Thanh Hoa in 2018 was 2,866,006 tons; $\mathrm{CO}_{2}$ emissions from cement industry in Thanh Hoa in 2018 was 8,529,359 tons; hence the total emissions of two sectors in Thanh Hoa in 2018 was 11,395,545 tCO2. 
$\mathrm{CO}_{2}$ emissions from thermal power industry in Quang Ninh in 2018 was 26,625,816 tons; $\mathrm{CO}_{2}$ emissions from cement industry in Quang Ninh in 2018 was 5,312,416 tons; therefore the total emissions of two sectors in Quang Ninh in 2018 was 31,938,232 $\mathrm{tCO}_{2}$.

\section{Carbon Absorption and Storage Capacity of the Forests in Thanh Hoa and Quang Ninh}

Carbon Absorption and Storage Capacity of Thanh Hoa's Forest

Data on area, reserve and type of forest types in Thanh Hoa are summarized in Table 4. The total area of forested land is $587,009.8 \mathrm{~m}^{2}$ with the volume of reserve is $28,755,013 \mathrm{~m}^{3}$.

Table 4. Area And Reserve Capacity Of All Forest Types In Thanh Hoa

\begin{tabular}{|c|c|c|c|}
\hline No & Type Of Forest & $\operatorname{Area}\left(\mathbf{m}^{2}\right)$ & Reserve $\left(\mathrm{m}^{3}\right)$ \\
\hline 1 & Total area of forested land & $587,009.8$ & $28,755,013$ \\
\hline 2 & Natural forest & $395,164.4$ & $24,149,783$ \\
\hline 3 & Rich forest & $8,554.8$ & $1,836,451$ \\
\hline 4 & Medium forest & $42,234.0$ & $5,689,857$ \\
\hline 5 & Poor forest & $230,149.9$ & $12,462,858$ \\
\hline 6 & Other natural forests & $111,181.1$ & $4,160,618$ \\
\hline 7 & Plantation forest & $191,845.4$ & $4,605,230$ \\
\hline 8 & Wood plantation & $179,471.3$ & $4,088,464$ \\
\hline 9 & Rubber plantation & $11,219.0$ & 480,639 \\
\hline 10 & Plantation of specialty trees & 288.6 & 9,741 \\
\hline 11 & Mangroves & 481.8 & 7,184 \\
\hline 12 & Forest planted on sand & 384.7 & 19,202 \\
\hline 13 & Land without forest planning for forestry & $97,011.1$ & - \\
\hline
\end{tabular}

The carbon storage capacity of all forest types in the province is calculated. Thus, the total reserve of $\mathrm{CO}_{2}$ in Thanh Hoa in 2018 were 35,762,557.92 tons from natural forest and 5,815,057.18 from plantation forest. Table 5 presents the carbon sequestration and storage capacity calculated of Thanh Hoa forest in 2018, of which the absorption capacity was $4,302,474.12 \mathrm{tCO}_{2}$ /year and the storage capacity was 40,055,020 $\mathrm{tCO}_{2}$. 
Table 5. Carbon Absorption and Storage Capacity of Thanh Hoa Forest in 2018

\begin{tabular}{|c|c|c|c|c|}
\hline Type of Forest & $\begin{array}{r}\text { Total Area } \\
\text { (ha) }\end{array}$ & $\begin{array}{r}\text { Ave. Reserve } \\
\left(\mathbf{m}^{3} / \mathbf{h a}\right)\end{array}$ & $\begin{array}{r}\text { Total Reserve } \\
\left(\mathrm{tCO}_{2}\right) \\
\end{array}$ & $\begin{array}{r}\text { Total Absorption } \\
\left(\mathrm{tCO}_{2} / \text { year }\right)\end{array}$ \\
\hline Total forest area & $589,009.80$ & - & $40,055,020.10$ & $4,302,474.12$ \\
\hline Natural forest & $392,504.16$ & 61.68 & $35,762,557.92$ & $1,760,637.85$ \\
\hline Plantation forest & $196,932.77$ & - & $5,815,057.18$ & $2,934,720.27$ \\
\hline
\end{tabular}

The evolution of Thanh Hoa forest area from 2005 to 2018 shows that the trend has increased significantly, so the ability to absorb and store carbon also increases.

Carbon Absorption and Storage Capacity of Quang Ninh's Forest

Data on forest area and reserves of Quang Ninh province are summarized in Table 6.

Table 6. Area and Reserve Capacity of all Forest Types in Quang Ninh

\begin{tabular}{|c|c|c|c|}
\hline No & Type Of Forest & Area $\left(\mathbf{m}^{2}\right)$ & Reserve $\left(\mathbf{m}^{3}\right)$ \\
\hline & Total area of forested land & $336,522.7$ & $16,663,082$ \\
\hline 1 & Natural forest & $124,295.0$ & $7,015,685$ \\
\hline 2 & Rich forest & 100.1 & 23,643 \\
\hline 3 & Medium forest & $7,464.8$ & 939,259 \\
\hline 4 & Poor forest & $99,647.8$ & $5,214,853$ \\
\hline 5 & Other natural forests & $17,082.4$ & 837,930 \\
\hline 6 & Plantation forest & $206,967.0$ & $9,647,397$ \\
\hline 7 & Wood plantation & $169,536.9$ & $8,595,541$ \\
\hline 8 & Plantation of specialty trees & $17,111.4$ & 794,232 \\
\hline 9 & Mangroves & $19,820.0$ & 235,932 \\
\hline 10 & Forest planted on sand & 498.7 & 21,692 \\
\hline 11 & Land without forest planning for forestry & $104,667.3$ & - \\
\hline
\end{tabular}


Table 7 presents the carbon sequestration and storage capacity calculated of Quang Ninh forest in 2018, of which the absorption capacity was 3,191,060 $\mathrm{tCO}_{2} /$ year and the storage capacity was $22,988,159 \mathrm{tCO}_{2}$.

Table 7. Carbon Absorption and Storage Capacity of Quang Ninh Forest in 2018

\begin{tabular}{lrrrr}
\hline Type of forest & $\begin{array}{r}\text { Total Area } \\
(\mathbf{h a})\end{array}$ & $\begin{array}{r}\text { Ave. } \\
\text { Reserve } \\
\left(\mathbf{m}^{\mathbf{3}} \mathbf{h a}\right)\end{array}$ & $\begin{array}{r}\text { Total Reserve } \\
\left(\mathbf{t C O}_{\mathbf{2}}\right)\end{array}$ & $\begin{array}{r}\text { Total Absorption } \\
(\mathbf{t C O} / \mathbf{y e a r})\end{array}$ \\
\hline Total forest area & $336,522.70$ & - & $22,988,159.16$ & $3,191,060.41$ \\
Natural forest & $123,449.52$ & 61.68 & $10,397,809.70$ & $426,825.99$ \\
Plantation forest & $213,073.18$ & - & $12,600,349.45$ & $2,982,427.43$ \\
\hline
\end{tabular}

Summary of the Ability to Adsorb and Store Carbon in the Two Provinces' Forest

In 2018, total $\mathrm{CO}_{2}$ emissions from thermal power and cement industry in Thanh Hoa and Quang Ninh were 11,395,545 tons, and 31,938,232 tons, respectively. In 2018, $\mathrm{CO}_{2}$ storage capacity of all forest types in Thanh Hoa and Quang Ninh were 40,055,020 tons and 22,988,159 tons, respectively; $\mathrm{CO}_{2}$ absorption capacity of all forest types in these two provinces were $4,302,474$ tons and 3,191,060 tons, accordingly. It means about $38 \%$ of $\mathrm{CO}_{2}$ emitted in the year from these industries can be absorbed by the forests in Thanh $\mathrm{Hoa}$ and about $10 \%$ of $\mathrm{CO}_{2}$ emitted in the year from these industries can be absorbed by the forests in Quang Ninh. Yearly calculation also finds out that more than $17 \%$ of $\mathrm{CO}_{2}$ emitted from both industries can be absorbed by the forests in both provinces.

\section{Conclusions}

This study focuses on evaluation of forest environmental services and brings an important basis for C-PFES. Thanh Hoa and Quang Ninh provinces are selected for investigating $\mathrm{CO}_{2}$ emissions from coal-fired thermal power and cement plants as well as carbon sequestration capacity of the provinces' forests over 5 years (2013-2018). The study has found that the average emission factor for PC, CFB and rotary kiln cement technology was $1.05 \mathrm{tCO}_{2} / \mathrm{MWh}$, $1.11 \mathrm{tCO}_{2} / \mathrm{MWh}$ and $0.85 \mathrm{tCO}_{2} / \mathrm{ton}$ of clinker, respectively. In $2018,38 \%$ of $\mathrm{CO}_{2}$ emitted from both industries can be absorbed by the forests in Thanh $\mathrm{Hoa}$ and $10 \%$ of $\mathrm{CO}_{2}$ emitted from both industries can be absorbed by the forests in Quang Ninh. In some GHG reduction schemes such as C-PFES, a price is set for GHGs (usually $\mathrm{CO}_{2}$ ), then producers can pay when they emit or consume products that emit $\mathrm{CO}_{2}$ (such as coal, cement). C-PFES allows the $\mathrm{CO}_{2}$ producers to estimate actual emissions costs, provide a strong incentive to adjust business models and technologies with lower emissions and/or identify ways to address their emissions. This study proves that heavy industries such as thermal power and cement in Thanh Hoa and Quang Ninh can be chosen to fully tackle their GHG emission reductions (from 10 - 38\%) through C-PFES if this scheme is applicable in the provinces. It is suggested that, with its 
potential benefits, C-PFES will contribute to the implementation of Vietnam's green growth strategy and the Government's commitment to reduce GHG emissions and increase the forest cover as well.

\section{Acknowledgements}

This research was conducted with the support from the United States Agency for International Development (USAID). The authors wish to thank Mr. Brian Bean and Ms. Nga Dang (Winrock International Institute for Agricultural Development) for their valuable discussion.

\section{References}

[1] T. Locatelli, T. Binet, J.G Kairo, L. King, S. Madden, G. Patenaude, C. Upton, and M. Huxham, "Turning the tide: How blue carbon and payments for ecosystem services (PES) might help save mangrove forests," $A M B I O$, Vol. 43, No. 8, pp. 981-995, 2014. doi: 10.1007/s13280-014-0530-y

[2] D.M. Alongi, "Carbon payments for mangrove conservation: Ecosystem constraints and uncertainties of sequestration potential," Environmental Science \& Policy, Vol. 14, No. 4, pp. 462-470, 2011. doi: 10.1016/j.envsci.2011.02.004

[3] M.S. Reed, K. Allen, A. Attlee, A.J Dougill, K.L. Evans, J.O. Kenter, A.S. Scott, M.A. Smyth, L.C. Stringer, and M.J. Whittingham, "A place-based approach to payments for ecosystem services," Global Environmental Change, Vol. 43, pp. 92-106, 2017. doi: 10.1016/j.gloenvcha.2016.12.009

[4] E. H. Bulte, L. Lipper, R. Stringer, and D. Zilberman, "Payments for ecosystem services and poverty reduction: concepts, issues, and empirical perspectives," Environment and Development Economics, Vol. 13, No. 3, pp. 245-254, 2008. doi: 10.1017/S1355770X08004348

[5] M.N. Noordwijk, B. Leimona, R. Jindal, G.B. Villamor, M. Vardhan, S. Namirembe, D. Catacutan, J. Kerr, P.A. Minang, and T.P. Tomich, "Payments for environmental services: evolution toward efficient and fair incentives for multifunctional landscapes," Annual Review of Environment and Resources, Vol. 37, pp. 389-420, 2012. doi: 10.1146/annurevenviron-042511-150526

[6] MONRE Vietnam, The second biennial updated report of Vietnam to the UNFCCC [Online]. Available: https://unfccc.int/documents/180729. [Accessed: June 2019]

[7] MONRE Vietnam, The first biennial updated report of Vietnam to the UNFCCC [Online]. Available: https://unfccc.int/documents/180728. [Accessed: June 2019]

[8] Intergovernmental Panel on Climate Change (IPCC), IPCC Guidelines for National Greenhouse Gas Inventories - Energy, Institute for Global Environmental Strategies (IGES), Japan, 2006 [Online]. Available: https://www.ipcc-nggip.iges.or.jp/public/2006gl/vol2.html [Accessed: June 2019]

[9] Intergovernmental Panel on Climate Change (IPCC), IPCC Guidelines for National Greenhouse Gas Inventories - Industrial Processes and Product Use, Institute for Global Environmental Strategies (IGES), Japan, 2006 [Online]. Available: https://www.ipccnggip.iges.or.jp/public/2006gl/vol3.html [Accessed: June 2019] 
[10] FPT Securities, Cement Industry Update Report, Vietnam, 2020 [Online]. Available: http://www.fpts.com.vn/FileStore2/File/2020/05/14/Eng_Cement_Industry_Update042020 _4d1632a8.pdf [Accessed: November 2020]

[11] Intergovernmental Panel on Climate Change (IPCC), IPCC Guidelines for National Greenhouse Gas Inventories - Agriculture, Forestry and other Land Use, Institute for Global Environmental Strategies (IGES), Japan, 2006 [Online]. Available: https://www.ipccnggip.iges.or.jp/public/2006gl/vol4.html [Accessed: June, 2019]

[12] Issuing the Results of the Forest Inventory in Quang Ninh Province, Quang Ninh People's Committee Decision No. 680/QD-UBND, March 14, 2016.

[13] Issuing the Results of the Forest Inventory in Thanh Hoa Province, Thanh Hoa People's Committee Decision No. 5429/QD-UBND, December 24, 2015.

[14] Promulgating the Regulation on Piloting Benefit Sharing from REDD+ within the Framework of Implementing the UN-REDD Vietnam Program - Phase II, Ministry of Agriculture and Rural Development (MARD) Decision No. 5399/QD-BNN-TCLN, December 25, 2015.

[15] Solomon, S., D. Qin, M. Manning, R.B. Alley, T. Berntsen, N.L. Bindoff, Z. Chen, A. Chidthaisong, J.M. Gregory, G.C. Hegerl, M. Heimann, B. Hewitson, B.J. Hoskins, F. Joos, J. Jouzel, V. Kattsov, U. Lohmann, T. Matsuno, M. Molina, N. Nicholls, J. Overpeck, G. Raga, V. Ramaswamy, J. Ren, M. Rusticucci, R. Somerville, T.F. Stocker, P. Whetton, R.A. Wood, and D. Wratt, Technical Summary. In: Climate Change 2007: The Physical Science Basis. Contribution of Working Group I to the Fourth Assessment Report of the Intergovernmental Panel on Climate Change, Cambridge University Press, Cambridge, United Kingdom and New York, New York, USA, 2007 [Online]. Available: https://www.ipcc.ch/site/assets/uploads/2018/02/ar4-wg1-ts-1.pdf [Accessed: June 2019] 